\title{
WPŁYW WARUNKÓW ATMOSFERYCZNYCH NA NIEMIECKIE GASIENICOWE WOZY BOJOWE PODCZAS OPERACJI „BARBAROSSA” W ZWIAZZKU SOWIECKIM OD CZERWCA DO GRUDNIA 1941 ROKU
}

Streszczenie. Po rozpoczęciu w czerwcu 1941 r. operacji „Barbarossa”, wojska niemieckie walczące w Związku Sowieckim musiały zmagać się nie tylko z Rosjanami, lecz także z ich potężnym sojusznikiem - pogodą; najpierw z suchym i gorącym latem, potem deszczową jesienią a na końcu ostrą, mroźną i przedwczesną zimą. Skrajne warunki atmosferyczne, jakie panowały w III i IV kwartale 1941 r. przyczyniły się po stronie niemieckiej do powstania szeregu problemów, począwszy od tych związanych z logistyką (m.in. trudnościami w transporcie zaopatrzenia), a skończywszy na odciśnięciu piętna na morale żołnierzy. Upał, kurz, piach, błoto, a potem bardzo niskie temperatury oraz śnieg nie pozostawały również bez wpływu na użytkowany sprzęt pancerny, w tym czołgi i inne gąsienicowe wozy bojowe, znajdujące się na wyposażeniu niemieckich wojsk pancernych.

Słowa kluczowe: zima 1941 r., śnieg, błoto, pył, kurz, czołgi, Barbarossa

Zgodnie z przewidywaniami $\mathrm{OKH}^{1}$ oraz samego Adolfa Hitlera, kampania przeciwko Związkowi Sowieckiemu miała potrwać kilkanaście tygodni, a niemieccy żołnierze święta Bożego Narodzenia w roku 1941 mieli spędzić $\mathrm{w}$ rodzinnym gronie. Takie założenie z punktu widzenia planowania strategicznego sprawiło, że niewiele uwagi poświęcono przygotowaniu Wehrmachtu na wypadek niezakończenia walk w zakładanym czasie i prowadzenia ich w porze

\footnotetext{
${ }^{1} \mathrm{OKH}$ - Oberkommando des Heeres - niemieckie Naczelne Dowództwo Wojsk Lądowych.
} 
późnojesiennej oraz zimowej. W efekcie, gdy jesienią 1941 r. stało się jasne, że podstawowe cele planu „Barbarossa” nie zostaną osiągnięte przed nadejściem pory zimowej, niemieccy dowódcy zdali sobie sprawę z faktu, że ich wojska są nieprzygotowane do prowadzenia działań wojennych w takich warunkach klimatycznych, w dodatku na bardzo rozległym obszarze. Nie mogło być jednak inaczej, zważywszy zwłaszcza na okoliczność, iż Niemcy przygotowując plan ataku na Związek Sowiecki, pominęli kwestie związane z analizą warunków atmosferycznych, na jakie mogła natknąć się atakująca armia ${ }^{2}$.

Na trzy tygodnie przed rozpoczęciem agresji na Związek Sowiecki, 1 czerwca 1941 r. na stanie niemieckich wojsk lądowych znajdowały się 5162 czołgi $^{3}$, z których 1951 stanowiły lekkie wozy typu Pz.Kpfw. I i Pz.Kpfw. II, słabo uzbrojone i opancerzone, nie spełniające wymagań taktyczno-technicznych, jakie stawiało przed nimi ówczesne pole walki. Sam Pz.Kpfw. I, jako czołg zaprojektowany w 1934 r. i dysponujący zaledwie dwoma karabinami maszynowymi M.G. 13 i grubością płyt pancerza sięgającą maksymalnie $13 \mathrm{~mm}$ (nie wliczając jarzma), zaprezentował nikłą wartość bojową już podczas konfliktu w Hiszpanii w latach 1936-1939, w którym wozy te brały udział w składzie Panzergruppe Drohne ${ }^{4}$. Resztę czołgów, w liczbie 3211 maszyn, stanowiły eks-czeskie Pz.Kpfw. 35(t) oraz 38(t), Pz.Kpfw. III oraz Pz.Kpfw. IV, które były uzbrojone w armaty o kalibrach odpowiednio 37, 37 i 50 (w zależności od wersji) i $75 \mathrm{~mm}$. Teoretycznie tylko ostatni z wymienionych pojazdów, w wersjach $\mathrm{D}$ i $\mathrm{E}^{5}$ zdawał się posiadać na tyle silne opancerzenie $\left(\right.$ do $50 \mathrm{~mm}^{6}$ ) i skuteczną armatę, aby z powodzeniem móc nawiązać w miarę równorzędną walkę z sowieckimi T-34.

2 R. FORCZyK, Wojna pancerna na froncie wschodnim 1941-1942. Schwerpunkt, Warszawa 2019, s. 38 .

3 T.L. Jentz, Panzertruppen. The Complete Guide to the Creation \& Combat Employment of Germany's Tank Force 1933-1942, vol. 1, Atglen 1996, s. 186.

4 K.R. Pawlas, Panzerkampfwagen I (MG), „Waffen Revue” 1975, nr 17, s. 2773-2778; T.L. Jentz, H.L. Doyle, Panzerkampfwagen I Kleintraktor to Ausf. B, Boyds 2002, s. 1-99. Jarzmo, w którym umieszczone były dwa karabiny maszynowe, miało grubość $15 \mathrm{~mm}$. Więcej na temat udziału czołgów Pz.Kpfw. I zgrupowanych w Panzergruppe Drohne vide: H. Michalski, Panzergruppe Drohne w hiszpańskiej wojnie domowej. Zarys historii dziatań w latach 1936-1939, „Militaria XX wieku" 2013, nr 52, ss. 46-53.

5 Niem. Ausfübrung.

6 T.L. Jentz, H.L. Doyle, Panzerkampfwagen IV - Grosstraktor to Panzerbefehlswagen IV, Darlington 1997, s. 4-29, 4-38. 
Z podanej powyżej ogólnej liczby, w dniu 22 czerwca $1941 \mathrm{r}$. Wehrmacht skierował przeciwko Armii Czerwonej 3502 czołgi, z których aż 1093 stanowiły wozy typu Pz.Kpfw. I i II7. Po drugiej stronie stanęli Rosjanie posiadający około 20 000-22 7008 czołgów, w tym 1225 T-34, ponieważ tyle tych wozów Armia Czerwona zdołała odebrać z zakładów produkcyjnych do momentu wybuchu konfliktu?.

Pierwsze oznaki negatywnego wpływu warunków atmosferycznych na niemieckie wojska zmechanizowane i znajdujące się na ich wyposażeniu gąsienicowe wozy bojowe, pojawiły się już w czerwcu i lipcu 1941 r. Panujące wówczas upalne lato, podczas którego temperatura powietrza przekraczała $40^{\circ} \mathrm{C}^{10}$ sprawiło, że rosyjskie drogi pokryły się drobnym pyłem, a przejazd jakiegokolwiek pojazdu wzniecał w górę gęsty obłok zanieczyszczeń. Drobiny unoszącego się w powietrzu piachu i kurzu były szczególnie niebezpieczne dla wszystkich wozów mechanicznych, a dostając się do filtrów powietrza i chłodnic czołgowych silników często powodowały ich przegrzanie ${ }^{11}$, co w skrajnych przypadkach mogło doprowadzić nawet do zatarcia jednostek napędowych. Te z kolei były na wagę złota, cały czas ich bowiem brakowato ${ }^{12}$. Generał Heinz Guderian w wystąpieniu w dniu 18 listopada 1941 r. przed specjalną komisją ds. czołgów stwierdził, że: „W kampanii rosyjskiej napotkaliśmy nieznane nam dotychczas przeszkody terenowe. W lecie przede wszystkim kurz, który bardzo szybko uszkadzał silniki”'13. Awarie motorów niemieckich gąsienicowych wozów bojowych, będące efektem długich przemarszów i działania wspomnianych zanieczyszczeń stały się na tyle częste i uciążliwe dla personelu jednostek warsztatowych, że Niemcy pośpiesznie wprowadzali w większej liczbie do użytku np. samochody ciężarowe lub ciągniki półgąsienicowe wyposażone w dźwig, aby móc taką naprawę wy-

7 B. KAVALERCHIK, The tanks of operation Barbarossa. Soviet versus German armour on the eastern front, Barnsley 2018, s. 62.

8 R.A. Slayton, Niszczycielska broń, Warszawa 2017, s. 133; T. Anderson, Pantera. Legendarny czotg, Warszawa 2018, s. 17.

9 J. Nikołajuk, Dostawy czotgów nowych typów i ich użytkowanie w korpusach zmechanizowanych RKKA stacjonujących na Biatostocczyźnie (październik 1940 - czerwiec 1941), „Zeszyt Naukowy Muzeum Wojska” 2018, nr 31, s. 182.

${ }^{10}$ E. Durschmied, Jak pogoda zmieniata losy wojen i świata, Warszawa 2017, s. 181.

${ }^{11}$ Ibidem, s. 181.

12 G.E. Blau, Niemiecka kampania w Rosji. Planowanie i operacje (1940-1942), Oświęcim 2014, s. 81 .

13 T. Anderson, op. cit., s. 27. 
konać nawet $\mathrm{w}$ najcięższych warunkach polowych ${ }^{14}$. Problem awarii silników wywołany przez kurz i pył wznoszący się podczas jazdy rosyjskimi bezdrożami Niemcy starali się rozwiązać wprowadzając do służby w 1942 r. czołgi ciężkie Pz.Kpfw. VI „Tiger”, które w okresie od listopada 1942 r. do października 1943 r., miały już fabrycznie montowane zewnętrzne filtry powietrza typu „Feifel”15. Niemcy postąpili tak prawdopodobnie dlatego, że czołg ten stanowił ich główną nadzieję na zniwelowanie przewagi ilościowej, jaką dysponowała armia sowiecka, stąd też nie chcieli, aby zamiast walczyć na linii frontu, większość czasu spędzał na naprawach w oddziałach naprawczych.

Skrajne upały dały się we znaki również niemieckim pancerniakom, którym wewnątrz czołgów doskwierała wysoka temperatura i duchota, powodujące m.in. szybkie zmęczenie oraz utratę koncentracji. Prowadzenie walki przy otwartych włazach, w celu wymuszenia obiegu powietrza, w ogóle nie wchodziło w grę ze względu na bezpieczeństwo. Z kolei wentylatory zamontowane wewnątrz pojazdów służyły przede wszystkim do usunięcia z przedziału bojowego nadmiaru gazów prochowych powstałych po wystrzale, a nie stricte nawiewowi świeżego powietrza. Problem nagrzewających się płyt pancerza, które oddawały ciepło do wnętrza czołgów okazał się dla Niemców na tyle niepokojący i istotny do rozwiązania, że bazując na doświadczeniach kampanii w Związku Sowieckim oraz na froncie afrykańskim, w listopadzie 1941 r., w podbitej Grecji przeprowadzili oni testy czołgu Pz.Kpfw. II Ausf. B wyposażonego w swoistego rodzaju „płachtę przeciwsłoneczną", rozciągniętą na wieży i nadbudówce pojazdu. W założeniach inżynierów, miała ona nie dopuszczać do zbytniego nagrzewania się płyt pancernych. Obecnie nie wiadomo, w jakim stopniu owa „narzuta” spełniała postawione przed nią wymagania, jednakże podczas przeprowadzonych prób w cieniu, w temperaturze powietrza od $28^{\circ} \mathrm{C}$ do $30^{\circ} \mathrm{C}$, w pozbawionym płachty czołgu zanotowano temperaturę: $63^{\circ} \mathrm{C} \mathrm{w}$ przedziale silnikowym, $101^{\circ} \mathrm{C} \mathrm{w}$ obrębie skrzyni biegów, $47^{\circ} \mathrm{C}$ na wysokości głowy kierowcy oraz $55^{\circ} \mathrm{C}$ w okolicach

${ }_{14}$ Przykładem takiego półgąsienicowego pojazdu wyposażonego w dźwig był np. ciągnik Sd.Kfz.9 mit Bilsteinkranaufbau (vide: S. KöNIG, FAMO 18t, Krefeld 2001, s. 49-54) lub Drehkrankraftwagen 18t Sd.Kfz. 9/1 (vide: ibidem, s. 55-68). O historii samego ciągnika vide: T. ANDERSON, FAMO schwerer Zugkraftwagen $18 t$ - (Sd.Kfz.9), Genova 2006 lub W.J. SPIELBERGer, Halftracked Vehicles of the German Army 1909-1945, Atglen 2008, s. 86-91.

15 T.L. Jentz, H.L. Doyle, Germany's Tiger Tanks. D.W. to Tiger I: Design, Production \& Modifications, Atglen 2000, s. 74-75. 
stóp kierowcy ${ }^{16}$. Łatwo zatem wyobrazić sobie, że gdyby czołg wystawiono bezpośrednio na oddziaływanie promieni najbliższej ziemi gwiazdy, odnotowana temperatura byłaby znacznie wyższa ${ }^{17}$. Dla pełnego obrazu sytuacji należy w tym miejscu także dodać, że Niemcy przed przybyciem do Afryki Północnej Niemieckiego Korpusu Afrykańskiego (luty 1941), wprowadzili w części użytkowanych czołgów (np. Pz.Kpfw. IV Ausf. D, Pz.Kpfw. IV Ausf. E) modyfikacje polegające m.in. na dodaniu specjalnych żaluzji nad przedziałem silnikowym, których zadaniem było zapewnienie lepszego odprowadzenia ciepła i umożliwienie operowania w gorącym klimacie (powyżej $\left.28^{\circ} \mathrm{C}\right)^{18}$. Tak zmodernizowane pojazdy posiadały w swoim oznaczeniu przedrostek „Tp” (z niem. Tropen).

Niemieccy stratedzy, planując ofensywę przeciwko swemu niedawnemu sojusznikowi, w ogóle nie wzięli pod uwagę tzw. błota sezonowego, wyjątkowo uciążliwego i występującego w Związku Sowieckim dwa razy w roku, w porze zwanej rasputica ${ }^{19}$. Powstałe pod wpływem roztopów (porą wiosenną) i intensywnych deszczy (pora jesienna) błoto sprawiło, że gruntowe rosyjskie „drogi” zamieniały się w niezwykle trudne do przebycia dla pojazdów gąsienicowych bagniste trakty komunikacyjne, nie mówiąc już nawet o samochodach, dla których stawały się one po prostu nieprzejezdne. Tak jesień 1941 r., w okresie przygotowań do ataku na Tułę, wspominał późniejszy generał, Hasso von Manteuffel: „Właśnie wtedy zaczęły się intensywne jesienne opady. Wszystkie drogi zamieniły się w bagniste koryta. Nieustannie grzęzły w nich całe kolumny. Piechociarzy z pułku Grossdeutschland, którzy nie byli w stanie przemieszczać się samodzielnie, trzeba było usadowić na pancerzach czołgów. Grupa bojowa dobrnęła wreszcie do Tuły, ale nie była już w stanie jej zdobyćc ${ }^{20}$. Podobne

16 T.L. Jentz, H.L. Doyle, Panzerkampfwagen II Ausf. D, E, and F development and production from 1937 to 1942, Boyds 2010, s. 2-47.

17 Osobna pozostawała kwestia wykorzystania czołgu wyposażonego w opisywaną płachtę na polu walki, ponieważ po założeniu znacznie ograniczała ona widoczność załogi, zwłaszcza żołnierzom znajdującym się w wieży. Niemcy szybko zauważyli ten mankament - zaproponowano, że płachta mogłaby być używana w trakcie przemarszów lub postoju, podczas którego chroniłaby czołg przed nagrzaniem, pyłem i kurzem.

${ }_{18}$ Niem.: Deutsches Afrikakorps (DAK); W.J. Spielberger, T.L. Jentz, H.L. Doyle, op. cit., s. $149,157$.

19 C.E. Wood, Wielkie porażki militarne. Jak pogoda wptynęta na losy wojen, Warszawa 2007, s. $51-52$.

${ }^{20}$ F. Kurowski, Bitwy pancerne II wojny światowej we wspomnieniach Hasso von Manteuffla, Kraków 2012, s. 85. 
spostrzeżenia wyraził w październiku 1941 r. gen. Heinz Guderian: „Pojazdy kołowe mogły się poruszać jedynie wtedy, gdy ciągnęły je pojazdy gąsienicowe, te zaś, przy ich konstrukcji nie obliczonej na tak wielkie obciążenie, ulegały nadmiernemu zużyciu. $Z$ braku łańcuchów i innych środków do sprzęgania pojazdów, samoloty zrzucały wiązki sznurów, aby dopomóc pojazdom, które ugrzęzły w drodze. Załogi setek tych wozów musiano przez całe tygodnie zaopatrywać z powietrza. W ogóle przygotowania do kampanii zimowej były w stanie opłakanym. Nie nadchodziła ani zapotrzebowana 8 tygodni wcześniej glizantyna do chłodnic silników, ani odzież zimowa dla wojsk"21. Sytuację pogarszał dodatkowo fakt, że w Związku Sowieckiem zaledwie 7\% dróg miało utwardzoną nawierzchnię ${ }^{22}$. Warto w tym miejscu dodać, że zamarznięte błoto osiadłe na bieżniku gąsienicowym ${ }^{23}$ było $\mathrm{w}$ stanie nawet unieruchomić na pewien czas czołg, aż do momentu jego usunięcia. Niemcy zatem, w celu wyeliminowania potrzeby częstego czyszczenia takich elementów, jak np. koła kierunkowe, modyfikowali ich konstrukcję w taki sposób, aby poprzez odpowiednie wyprofilowanie były one zdolne do „samoczyszczenia” podczas jazdy. Tak przekonstruowane koło kierunkowe zastosowano np. w czołgu Pz.Kpfw. V „Panther”, stało się to jednak stosunkowo późno, montowano je bowiem w wozach produkowanych od października $1944 \mathrm{r}^{24}$

Zima, jaka nawiedziła ZSRR pod koniec 1941 r., bardzo ograniczyła, a na niektórych odcinkach frontu praktycznie sparaliżowała działania niemieckich wojsk lądowych na wszystkich strategicznych kierunkach uderzeń. W dużej mierze dotyczyło to także wojsk pancernych. Tak tę sytuację wspominał płk Hans von Luck: „Wehrmacht był zupełnie nieprzygotowany na działanie w warunkach zimy. Wzdłuż całego frontu północnego i środkowego wszelki ruch oddziałów został zatrzymany przez śnieg. Najgorzej miała piechota i motocykliści, ponieważ nie mieli żadnej osłony" ${ }^{25}$. Wszystkim użytym przez Niemców typom czołgów doskwierała gołoledź, przez którą ślizgały się one na drogach i podczas

${ }^{21}$ H. Guderian, Wspomnienia żotnierza, Warszawa 1991, s. 189-190.

22 C.E. Wood, op. cit., s. 53.

${ }^{23}$ Bieżnik gąsienicowy to część podwozia, składająca się z komponentów, za pomocą których czołg jest poruszany. Są to przede wszystkim: gąsienice, koła nośne, koła napędowe, koła kierunkowe.

24 T.L. Jentz, H.L. Doyle, Germany's Panther Tank. The Quest for Combat Supremacy, Atglen 1995, s. 96.

${ }^{25}$ H. von Luck, Bytem dowódca pancernym, Warszawa 2006, s. 96. 
jazdy w terenie (utrata przyczepności). Generał Heinz Guderian słusznie za taki stan rzeczy obwiniał gąsienice, gdyż jak sam stwierdził: „Gołoledź przysparzała wiele trudności, gdyż nie nadeszły zaczepy do gąsienic”26. Mówiąc o „zaczepach do gąsienic" miał na myśli tzw. ostrogi, czyli zaczepy przeciwślizgowe przykręcane do traków. Poddając słowa wspomnianego niemieckiego dowódcy krytycznej analizie można jednak wysnuć wniosek, że owe zaczepy nie mogły dotrzeć na front wschodni zimą 1941 r., ponieważ... taki osprzęt wówczas nie istniał. Konstrukcja gąsienic niemieckich czołgów użytych podczas „Barbarossy” nie pozwalała bowiem na przykręcenie do ogniw zaczepów przeciwpoślizgowych, zatem nie były one wytwarzane. Odnosząc się do wypowiedzi gen. H. Guderiana można dodać, iż jego nieprecyzyjne słowa dotyczące zaczepów do gąsienic wynikły najprawdopodobniej z powodu spisywania całości wspomnień już po zakończeniu II wojny światowej, a więc po upływie kilku lat, które mogły w pewnym stopniu zniekształcić przywoływany z pamięci obraz wydarzeń z roku 1941, zwłaszcza w przytoczonym fragmencie dotyczącym kwestii ściśle technicznych.

Aby zniwelować wpływ gołoledzi na stateczność czołgów, Niemcy na potrzeby Pz.Kpfw. III i Pz.Kpfw. IV zaczęli wytwarzać gąsienice, których ogniwa od strony oporowej były charakterystycznie ryflowane w celu zwiększenia przyczepności do gruntu ${ }^{27}$. Ich produkcja rozpoczęła się jednak dopiero w 1942 r., lecz szybko okazało się, że nie zapewniają one właściwości antypoślizgowych na takim poziomie, jakiego oczekiwano. W związku z tym w październiku 1942 r. do wspomnianych wyżej wozów (a także innych pojazdów gąsienicowych wykorzystujących ich podwozia) rozpoczęto produkcję docelowych „zimowych” gąsienic, które nazwano Winterketten ${ }^{28}$. Tworzące je ogniwa miały około $55 \mathrm{~cm}$ szerokości (standardowe $38 \mathrm{~cm}$ ), z czego mniej więcej 1/3 przypadała na odlany wraz z nimi zaczep przeciwpoślizgowy.

Wyjątkowo wymagająca dla niemieckich kierowców okazywała się również jazda w głębokim śniegu. W takiej sytuacji czołgi często w nim grzęzły, osiadając

${ }^{26}$ H. Guderian, op. cit., s. 198.

27 Ogniwa gąsienic czołgów Pz.Kpfw. III i Pz.Kpfw. IV otrzymały specjalne wypusty (niem. Profilstollen), które miały zwiększać ich przyczepność do gruntu i zapobiegać wpadaniu czołgów w poślizg. P. Schwarzmann, Panzerketten. Die Gleisketten der deutschen Kettenfahrzeuge des Zweiten Weltkriegs, Königswinter 2013, s. 76.

${ }^{28}$ Ibidem, s. 77. 
dnem na podłożu, przez co ciężar zaczepienia pojazdu przekazywany był na podłoże nie tylko przez traki, ale również przez spód kadłuba i to w sposób niekontrolowany ${ }^{29}$. To powodowało, że gąsienice całkowicie traciły przyczepność. Przyczyną takiego stanu rzeczy (grzęźnięcia), podobnie jak w przypadku ślizgania się po nawierzchni w momencie wystąpienia gołoledzi, była przynajmniej częściowo konstrukcja samych traków niemieckich pojazdów, a mówiąc w tym przypadku precyzyjniej, fakt że wskutek stosunkowo niedużej szerokości i ażurowej budowy ogniw, nie rozkładały one należycie na gruncie ciężaru czołgów ${ }^{30}$. Im większy jest bowiem nacisk jednostkowy na grunt wywierany przez czołg, tym większą będzie miał on tendencję do zakopywania się np. w śniegu. Problem ten Niemcy rozwiązali jednak dopiero w maju 1944 r., gdy wprowadzili do użytku gąsienice Ostketten ${ }^{31}$, które miały stanowić ostateczne antidotum na rasputice oraz ciężką zimę. Różniły się one od wspomnianych wcześniej Winterketten przede wszystkim tym, że mimo bardzo zbliżonej szerokości (około 56-57 cm), zaczep antypoślizgowy Ostketten stanowił tylko około 1/6 długości ogniwa, co wpłynęło na zwiększenie powierzchni oporowej, a tym samym zmniejszenie wartości nacisku jednostkowego na grunt.

Zima 1941 r. wiązała się dla Niemców także z wystąpieniem innych problemów eksploatacyjnych użytkowanego sprzętu pancernego, skorelowanych z panującą wówczas, bardzo niską temperaturą. Często nie wyłączano silników czołgów stojących na postoju przez całą noc lub co jakiś czas cyklicznie je odpalano, aby w krytycznej chwili ich motor nie zawiódł. Mróz powodował, że zamarzało paliwo, a przyrządy optyczne zachodziły wilgocią ${ }^{32}$. Pułkownik Hans von Luck tak wspominał zimę 1941 r.: „Nieprzygotowanie do prowadzenia działań w warunkach skrajnych mrozów miało katastrofalne skutki dla naszych czołgów i pojazdów kołowych. Letni olej był zbyt rzadki, a woda w chłodnicach zamarzała natychmiast. Wkrótce musieliśmy roztapiać lód codziennie rano lampami lutowniczymi oraz zdobywać wrzątek, gdy tylko zbliżyliśmy się do jakiejś wioski. W przeciwnym razie musieliśmy pozostawiać silniki pracu-

29 A. Antonow, B. Artamonow, B. Korobkow, E. Magidowicz, Czotg, Warszawa 1957, s. 560.

30 Ogniwa o budowie ażurowej rozkładają ciężar pojazdów gąsienicowych tylko zaczepami, natomiast ogniwa płaskie (takie, jakie miał np. czołg T-34), rozkładają ciężar całą swoją płaszczyzną, ponieważ nie posiadają żadnych wycięć.

31 T.L. Jentz, H.L. Doyle, Bergepanzerwagen, Boyds 2004, s. 16-10.

32 H. Guderian, op. cit., s. 198. 
jące przez całą noc. Żaden mieszkaniec zachodniej czy południowej Europy ani Ameryki nie potrafi wyobrazić sobie, co to znaczy walczyć w temperaturze rzędu 40 stopni poniżej zera oraz podczas zamieci śnieżnych"33.

Sytuacja frontowa niejednokrotnie sprawiała, że niemieccy pancerniacy musieli spędzać zimowe noce we wnętrzach swoich czołgów. Łatwo się domyślić, że w temperaturze rzędu kilkudziesięciu stopni poniżej zera egzystencja $\mathrm{w}$ środku stalowego pojazdu nie należała do przyjemnych ani komfortowych. Zima 1941 r. dobitnie unaoczniła Niemcom, że należałoby rozważyć wprowadzenie w gąsienicowych wozach bojowych pewnych rozwiązań konstrukcyjnych lub urządzeń, które zlikwidowałyby problem panującego wewnątrz chłodu i byłyby w stanie doprowadzić do podniesienia temperatury powietrza w czołgu. Takie urządzenie, nawiewające do wnętrza przedziału bojowego ciepłe powietrze od silnika, zastosowano w wozie Pz.Kpfw. V „Panther”34.

Podsumowując, niemiecki sprzęt pancerny nie był przygotowany do walki w warunkach klimatycznych, z jakimi w III i IV kwartale $1941 \mathrm{r}$. Wehrmacht zetknął się w Związku Sowieckim. Stało się tak przede wszystkim dlatego, że niemieccy sztabowcy przygotowując ofensywę nie przeprowadzili analizy warunków meteorologicznych, jakie są właściwe dla obszarów, które planowali zająć. Gąsienicowe wozy bojowe nie otrzymały zawczasu np. prefiltrów lub odpowiednio szerokich gąsienic, dzięki czemu możliwe stałoby się przynajmniej częściowe uniknięcie zasygnalizowanych w artykule trudności. Dotkliwa lekcja płynąca ze zdobytych jesienią i zimą 1941 r. doświadczeń zaowocowała wprawdzie wprowadzeniem przez Niemców pewnych rozwiązań mających poprawić m.in. mobilność pojazdów gąsienicowych w głębokim śniegu, jednakże ze względu na stopniową utratę inicjatywy strategicznej na froncie wschodnim, nie miały one już większego znaczenia dla przebiegu dalszych wydarzeń.

\footnotetext{
33 H. vON LUCK, op. cit., s. 97.

34 T.L. Jentz, H.L. Doyle, Germany's Panther..., s. 78.
} 


\section{BIBLIOGRAFIA}

\section{Źródła drukowane}

Guderian H., Wspomnienia żotnierza, Warszawa 1991.

Luck H. von, Bytem dowódca pancernym, Warszawa 2006.

\section{Opracowania}

Anderson T., FAMO Schwerer Zugkraftwagen 18t - (Sd.Kfz.9), Genova 2006.

Anderson T., Pantera. Legendarny czotg, Warszawa 2018.

Antonow A., Artamonow B., Korobkow B., Magidowicz E., Czotg, Warszawa 1957.

Blau G., Niemiecka kampania w Rosji. Planowanie i operacje (1940-1942), Oświęcim 2014.

Durschmied E., Jak pogoda zmieniata losy wojen i świata, Warszawa 2017.

Forczyk R., Wojna pancerna na froncie wschodnim 1941-1942. Schwerpunkt, Warszawa 2019.

Jentz T.L., Panzertruppen. The Complete Guide to the Creation \& Combat Employment of Germany's Tank Force 1933-1942, vol. 1, Atglen 1996.

Jentz T.L., Doyle H.L., Bergepanzerwagen, Boyds 2004.

Jentz T.L., Doyle H.L., Germany's Panther Tank. The Quest for Combat Supremacy, Atglen 1995.

Jentz T.L., Doyle H.L., Germany's Tiger Tanks. D.W. to Tiger I: Design, Production \& Modifications, Atglen 2000.

Jentz T.L., Doyle H.L., Panzerkampfwagen I Kleintraktor to Ausf. B, Boyds 2002.

Jentz T.L., Doyle H.L., Panzerkampfwagen II Ausf. D, E, and F development and production from 1937 to 1942, Boyds 2010.

Jentz T.L., Doyle H.L., Panzerkampfwagen IV - Grosstraktor to Panzerbefeblswagen IV, Darlington 1997.

Kavalerchik B., The Tanks of Operation Barbarossa. Soviet versus German Armour on the Eastern Front, Barnsley 2018.

König S., FAMO 18t, Krefeld 2001.

Kurowski L., Bitwy pancerne II wojny światowej we wspomnieniach Hasso von Manteuffla, Kraków 2012.

Michalski H., Panzergruppe Drohne w hiszpańskiej wojnie domowej. Zarys historii dziatań w latach 1936-1939, „Militaria XX wieku” 2013, nr 52, ss. 46-53. 
Nikołajuk J., Dostawy czotgów nowych typów i ich użytkowanie w korpusach zmechanizowanych RKKA stacjonujących na Biatostocczyźnie (październik 1940 - czerwiec 1941), „Zeszyt Naukowy Muzeum Wojska” 2018, nr 31, s. 182.

Pawlas K.R., Panzerkampfwagen I (MG), „Waffen Revue” 1975, nr 17, s. 2773.

Schwarzmann P., Panzerketten. Die Gleisketten der deutschen Kettenfahrzeuge des Zweiten Weltkriegs, Königswinter 2013.

Slayton R.A., Niszczycielska broń, Warszawa 2017.

Spielberger W.J., Jentz T.L., Doyle H.L., Panzerkampfwagen IV and it's variants 1939 -1945. Book 2, Atglen 2011.

Wood C.E., Wielkie porażki militarne. Jak pogoda wptynęta na losy wojen, Warszawa 2007.

Hubert Michalski

\title{
THE INFLUENCE OF WEATHER CONDITIONS ON GERMAN ARMOUR DURING OPERATION „BARBAROSSA" IN THE SOVIET UNION FROM JUNE TO DECEMBER 1941
}

\begin{abstract}
Summary. German tanks were not prepared for the weather conditions that prevailed in the autumn and winter of 1941 in the Soviet Union. Frequent engine failures caused by dust required a long repairs. During the winter, the vehicles got stuck in the snow, making it impossible to continue the attack. The Germans took steps to modernize the construction of their tanks so that they could cope better in heavy terrain, mud and deep snow.
\end{abstract}

Keywords: the winter of 1941, snow, mud, dust, tanks, Barbarossa 